\title{
Co-expression of Leptin and Leptin Receptor in Adenocarcinoma of the Colon in Malay Population
}

\author{
Saad M. Al-Shibli ${ }^{* 1}$, Norra Harun ${ }^{2}$, Muna Kh. Alkubaisi ${ }^{3}$ \\ ${ }^{1}$ Department of Basic Medical Sciences, College of Medicine, International Islamic University Malaysia, 25200 Kuantan, \\ Pahang, Malaysia \\ ${ }^{2}$ Department of Pathology, Hospital Tengku Ampuan Afzan, Pahang, Malaysia \\ ${ }^{3}$ Department of Gynaecology and Obstetrics, College of Medicine, International Islamic University Malaysia, 25200 \\ Kuantan, Pahang, Malaysia
}

Corresponding author: Saad M. Al-Shibli; salshibli2004@yahoo.com

Received 03 February 2020;

Accepted 18 February 2020;

Published 21 February 2020

\begin{abstract}
Objectives: To assess the role of leptin in human colonic adenocarcinoma and to establish its expression in Malay population patients by using immunohistochemistry study. Methodology: Immunohistochemical study (IHC) using antibodies against leptin and its receptor was applied to assess the expression of leptin and its receptor in 38 samples of adenocarcinoma of the colon among Malay population and compare this expression with that of the adjacent normal colon tissue. Results: All the 38 colon adenocarcinoma samples stained strongly (100\%) for leptin and 36 out of 38 also stained strongly for leptin receptor (95\%). The other $2(5 \%)$ stained weak (1+). However, the whole specimens of the normal adjacent colon tissue stained weakly (1+) for both leptin and leptin receptor. The expression of both hormones in cancer and normal tissue is significantly different $(\mathrm{p}<0.01)$. There was significant co-expression of both hormones in colonic cancerous tissue. $\underline{\text { Conclusions: }}$ Leptin/leptin receptor system may have a tumorigenic effect on the colon tissue, most likely by an autocrine process. Inhibition of leptin/leptin receptor system might be helpful in the prevention and management of colon cancer.
\end{abstract}

Keywords: Leptin, Leptin receptor, Expression, Adenocarcinoma, Colon, Malay

\section{Introduction}

Obesity is a state of excessive fat retainment in the body that is the consequence of an imbalance of caloric energy consumption and expenditure ${ }^{[1]}$. Regarded as a crisis, obesity is at an exponential rising rate worldwide, much so that it has been regarded as a pandemic to the more traditional epidemic. Malaysia, much like most developing countries, is experiencing a rise in obesity that is growing at an alarming rate ${ }^{[2]}$. The lifestyle associated with obesity is linked with various systemic changes that can be observed. Such changes, whether severe or mild, include alteration in the levels of insulin, insulin-like growth factor, steroid hormones, adiponectin and leptin. The variations in the levels of these bodily factors alter the nutritional balance and potentially nurture an environment that could favor tumorigenesis ${ }^{[3]}$.

Supported by epidemiological evidence, colorectal cancer is widely regarded as a leading cause of cancer-related deaths ${ }^{[4]}$. The evidence showed an interesting and compelling link between colon cancer and obesity. Both the disease and the linked excessive fat retention state are associated with similar factors. Inactive lifestyle, unbalanced diet, low consumption of fruits and vegetables, and limited fibers in the diet are factors of both conditions ${ }^{[5,6]}$, although a more direct, and scientifically competent, link between the two conditions requires further investigation. The vast majority of colon cancer, of more than $90 \%$, are adenocarcinomas that originate from the epithelial cells of the colonic mucosa. Subsequently, there are other rare types that include neuroendocrine, squamous cell, adenosquamous, spindle cell and undifferentiated carcinomas ${ }^{[7]}$.

The adipose tissue is responsible for the synthesis of numerous hormones and cytokines, which are known as adipokines, these include leptin, resistin, adiponectin, tumor necrosis factor-a, IL-6, and others ${ }^{[8-10]}$. The adipose tissue projects an effect upon other tissues carried out through the adipokines. Leptin is the most significant and widely studied obesity-related adipokine ${ }^{[11,12]}$.

Leptin's action is mediated via its receptor ${ }^{[13-15]}$. The leptin receptor has widely been a principal research targets, it is a major part of the leptin/leptin receptor hormonal system, which along with many other factors, has control of various organs and their functions. Even though leptin is largely associated with white adipose tissue, it possessed an astonishing feature of being majorly secreted by additional tissues such as the placenta ${ }^{[16,17]}$, breast ${ }^{[18]}$, colon ${ }^{[19]}$, stomach ${ }^{[20]}$, and others.

The adipokine leptin (meaning 'thin' from Latin), which was discovered in 1994 by Jeffery Friedman is mainly a product of 
adipose tissue. Its level in human blood is correlated to the amount of fat tissue and consequently to body mass index. Serum leptin level is significantly raised in obese individuals ${ }^{[21]}$. The main action of leptin is regulating energy balance alongside influencing reproductive and immune processes in various organs. Many recent researches showed that leptin could promote malignant development ${ }^{[22-24]}$. These researches presented high expression for both leptin and its receptor in many cancerous cells such as breast, endometrial, colon and gastric cancers in comparison to noncancerous tissue ${ }^{[25-27]}$. Notably, the hormone can increase tumor invasiveness and metastasis ${ }^{[28-30]}$. Co-expression of both leptin and leptin receptor hormones that occur in different cancer tissue, such as breast and endometrium and others, suggests that leptin might act in an autocrine manner, which affect the cancerous cells.

The racial difference in serum leptin is a well-documented fact. A study of Women's Health Across the Nation using data on 1876 women showed that there was significant race-ethnic difference existing in circulating leptin levels among AfricanAmerican women and Chinese and Japanese women, even after accounting for adiposity ${ }^{[31,32]}$.

In our previous study among Malaysian population that includes different races, a significant difference in leptin level was found between Malay and Chinese. The mean leptin level was $24.45 \mathrm{ng} / \mathrm{ml}$ for the Malay and $15.87 \mathrm{ng} / \mathrm{ml}$ for the Chinese ${ }^{[33]}$.

To avoid bias in racial effect of serum leptin on the carcinogenesis of the colon, we targeted the Malay race only from the Malaysian patients with colon cancer to investigate the expression of leptin and its receptor in the cancerous tissue of the colon.

In this study, we investigated the degree of leptin and leptin receptor expression in adenocarcinoma of the colon cancer specimens and did comparison of this expression with the normal adjacent colonic tissue using immunohistochemistry from patients from the Malay population.

\section{Methodology}

\section{Study samples}

Thirty-eight paraffin samples of adenocarcinoma of the colon were obtained from the pathology department in Hospital Tengku Ampuan Afzan (HTAA), Kuantan, Pahang, Malaysia. We excluded the rare types of colorectal carcinoma like neuroendocrine, squamous cell, adenosquamous, spindle cell and undifferentiated carcinomas. The samples were taken from colonic tumours that have been resected with adjacent normal colonic tissue for comparison. The patient selection and clinical diagnosis were done in collaboration with the HTAA histopathology department from year 2018 .

Tissue collection and preparation

\section{Table 1: Age, gender and tumor grade distribution.}

\begin{tabular}{|l|l|l|l|l|l|l|}
\hline Age & $30-40$ & $40-50$ & $50-60$ & $60-70$ & $70-80$ & $80-90$ \\
\hline$n=38$ & $4(10.52 \%)$ & $4(10.52 \%)$ & $6(15.78 \%)$ & $17(44.73 \%)$ & $5(13.15 \%)$ & $2(5.26 \%)$ \\
\hline Gender & female & Male & & & & \\
\hline$n=38$ & $15(39.47 \%)$ & $23(60.53 \%)$ & & & & \\
\hline Grade & Well differentiated & Moderately differentiated & Undifferentiated & & \\
\hline$n=38$ & $2(5.26 \%)$ & $34(89.4 \%)$ & $2(5.26 \%)$ & & \\
\hline
\end{tabular}

We evaluated leptin and its receptor expression in 38 histopathological blocks of adenocarcinoma of the colon with normal adjacent colon tissue.

All the colon adenocarcinoma samples (38 cases) stained strongly ( $2+$ or $3+)(100 \%)$ for leptin and 36 out of 38 also stained strongly for leptin receptor $(94.74 \%)$. The other 2 samples $(5.26 \%)$ stained weak $(1+)$. However, the total samples of normal colonic tissue stained weakly (1+) for the two hormones leptin and leptin receptor as in Table (2). The expression of both hormones showed significant difference between the cancerous and the normal adjacent colon tissue with a $\mathrm{P}$ value $(\mathrm{p}<0.01)$. Both hormones were seen in the cytoplasm and over the cell membrane. (Figure 1) 
Table 2: Rate of positively stained samples in IHC study of colon tissue $(\mathbf{P}<0.01)$

\begin{tabular}{|l|l|l|l|l|}
\hline & LEP & LEPR & \multicolumn{2}{l|}{} \\
\cline { 2 - 5 } & low & High & low & high \\
\hline Cancer Tissue & 0 & 38 & 2 & 36 \\
$\mathrm{~N}=38$ & $0 \%$ & $(100 \%)$ & $(5.26 \%)$ & $(94.74 \%)$ \\
\hline Adjacent Normal Colon tissue & 38 & 0 & 38 & 0 \\
$\mathrm{~N}=38$ & $(100 \%)$ & $0 \%$ & $(100 \%)$ & $0 \%$ \\
\hline
\end{tabular}
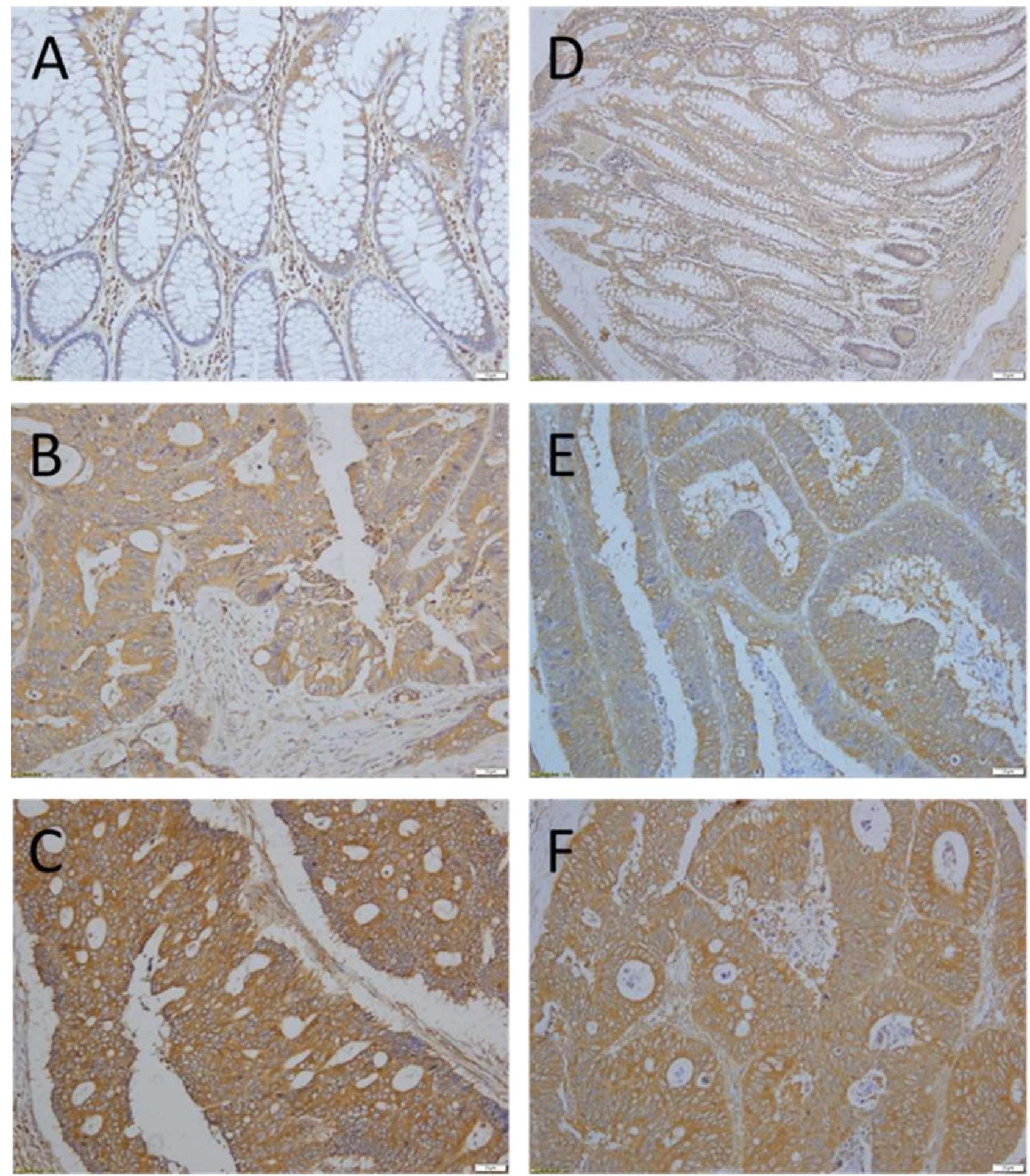

Figure 1: IHC staining of Leptin $(\mathbf{L})$ and Leptin receptor $(\mathbf{L R})$ in normal colonic tissue and cancer. A: $\mathbf{L}$ staining in normal colon tissue shows weak staining(1+); B: $\mathbf{L}$ staining in colon cancer (2+); C: $\mathbf{L}$ staining in colon cancer (3+); D: $\mathbf{L R}$ staining in normal colon tissue shows weak staining (1+); E: LR staining in colon cancer (2+); F: LR staining in colon cancer (3+).

Co-expression of leptin and its receptor in the colonic cancer tissue

The high expression of leptin receptor showed a significant correlation with the high level of leptin expression using chi-square test with a $p$ value of 0.011 (Figure 2). This indicates that there was co-expression of both hormones in the colon cancer cells. 


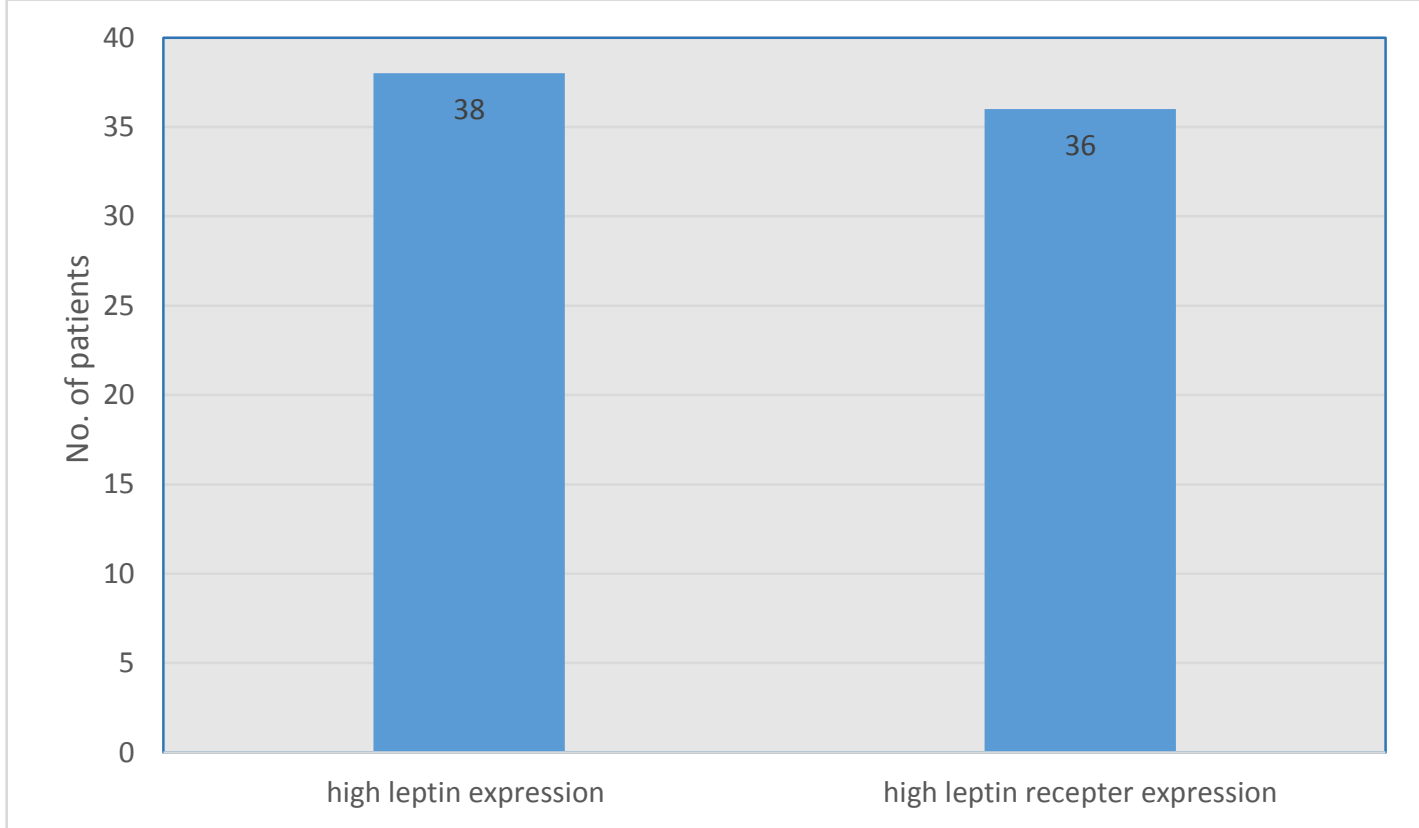

Figure 2: Co-expression of leptin and its receptor in the colon cancer cells

Any correlation between leptin/ leptin receptor expression in cancerous tissue or the adjacent normal tissue with any other variable is not possible because the grade of their expression is almost constant.

\section{Discussion}

The World Health Organisation considered colorectal cancer to be the third most common cancer among men worldwide and the second most common in women. These statistics are expected to rise annually through the coming two decades ${ }^{[36]}$. In Malaysia, colon cancer is reported as the most diagnosed cancer among males and the second after breast cancer in females. As far as racial statistics in Malaysia go, the Chinese have the highest incidence followed by the Indian and the Malay ${ }^{[37]}$. Various authors, including us, have published numerous articles correlating obesity with many types of cancer such as breast, ovary, and colon. Interestingly, an emerging evidence suggests that weight loss reduces cancer risk in adult ${ }^{[38-40]}$.

Leptin is a multifunctional hormone and is regarded as a growth factor for different tissues like human mammary gland ${ }^{[41]}$, hepatic cells ${ }^{[42]}$, epithelial cells of the colon ${ }^{[19]}$, bone tissue ${ }^{[43]}$, and others. A known fact for many growth factors, high amount of leptin can do tumorigenic effect on different tissues. Researchers found that leptin has an angiogenic and proliferative effect with an anti-apoptotic factor, suggesting its feasible role in the cancer development and its progress ${ }^{[44-46]}$. Thus, leptin could be the bridge between obesity and cancer. Several researches identified a causative link for leptin in the carcinogenesis of different organs, like ovary ${ }^{[47]}$, prostate ${ }^{[48]}$, esophagus ${ }^{[49]}$ and breast ${ }^{[50,51]}$. Riondino et al, in their work about the action of leptin on colon cancer, reported that leptin acts as a strong mitogen and has an anti-apoptotic action. This promotes the carcinogenesis development from normal colonic mucosa to adenoma and adenocarcinoma. The effect that is projected might indicate the involvement of leptin in multistep colon carcinogenesis ${ }^{[52]}$. Our study is aimed at clarifying such ambiguity regarding correlation of leptin with colon cancer.

Wang et al. and other researchers, like Stattin et al. reported that the serum leptin level was high in patients with colon cancer as compared to normal patients; this level tends to decrease after colectomy, which indicate a possible role for leptin in colon carcinogenesis ${ }^{[53,54]}$. However, others like Arpaci et al. and
Sălăgeanu et al. contradict this finding by mentioning that colon cancer patients have a low serum leptin level as compared to the control group ${ }^{[55,56]}$. This enigma in the role of leptin in the carcinogenesis of colon motivated us to do rigorous studies on this mysterious hormone through the study of leptin/leptin receptor expression among patients with colon cancer in a Malay population.

The racial difference in serum leptin is a well-documented fact. Therefore, we have chosen the Malay population in our study to avoid bias in racial effect of serum leptin on the carcinogenesis of the colon and because they are the major population in the Malaysian peninsula.

In our study, immunohistochemistry showed that all the 38 colonic adenocarcinoma samples stained strongly (100\%) for leptin and 36 out of 38 also stained strongly for leptin receptor (94.74\%). However, the total samples of normal colonic tissue stained weakly (1+) for the two hormones leptin and leptin receptor. Our result is adherent to data of preceding studies ${ }^{[26,57]}$. However Jeong, et al. reported that the level of leptin expression was $43.2 \%$ (Moderate) and $48.6 \%$ (High), while Koda et al, reported an expression for the leptin and leptin receptor to be $51.1 \%$ and $95.5 \%$ respectively. On the other hand, Al-Maghrabi et al. reported that leptin expression was present in $93.5 \%$ of the colonic cancer cases in Saudi Arabia, with high staining in only $22.75 \%$ of the cases ${ }^{[35]}$.

We found that both hormones were detected in the cytoplasm of the cancerous cell and were concentrated beneath the cell membrane. Meanwhile, Koda et al, mentioned that leptin was found in the cytoplasm and the microgranules of colon cancerous cells, while the leptin receptor staining found in the cell membrane as well as some occasional staining found in the nucleus ${ }^{[34]}$.

Interestingly, we noticed that the high expression of leptin in colon cancer showed a significant correlation with the high level of leptin receptor expression with a $p$ value of 0.011 . This indicates that there is a co-expression of leptin and leptin receptor in the cancerous cells of the colon. This co-expression proposes the presence of an organizational process in the expression of leptin and its receptor within the colonic tissue. It is possible to indicate 
that this action of leptin on adenocarcinoma of the colon is mostly an autocrine manner.

The literature shows much controversy in the relation between leptin/leptin receptor expressions with the clinicopathological features of colon cancer. In our study, we could not find any significant relation between leptin/leptin receptor expression with the clinico-pathological parameters like grade, stage and lymph node involvement. We think that this happened mainly for two reasons. The first is that any correlation between leptin/ leptin receptor expression in the colon cancer tissue or even in adjacent normal colonic tissue with any other variable is not possible because the grade of their expression in our study is almost constant. The second reason is, we think that our sample size is relatively small (38 cases) from a statistical point of view.

\section{Conclusion}

High expression of leptin and its receptor may play a positive role in the carcinogenesis of the colon possibly by an autocrine manner. However, further biochemical and molecular genetic studies are warranted to identify the exact role of leptin/leptin receptor system in colon cancer.

\section{Conflicts of Interest}

The authors declare that there is no conflict of interest regarding the publication of this paper.

\section{Funding Statement}

This work was funded by International Islamic University Malaysia (IIUM) through the research initiative grant scheme 17 (RIGS17082-0657).

\section{Authors' contributions}

Saad M. Al-Shibli designed the proposal of the study, principle investigator for the grant, coordinator for data collection, laboratory results \& data analysis.

Norra Harun prepared the histopathological specimens, did the assessment of the immunostaning of the samples and took the photos for the expression.

Muna Kh. Alkubaisi prepared figures and tables, reviewed and did proof reading for the final paper.

\section{Acknowledgements}

We are most grateful to our colleagues, and staff in the BMS Department, College of Medicine, IIUM; and to Histopathology Department, HTAA, Kuantan, Malaysia for their remarkable support.

\section{References}

[1] Hill, J. O., Wyatt, H. R., \& Peters, J. C. (2012). Energy balance and obesity. Circulation, 126(1), 126-132. https://doi.org/10.1161/CIRCULATIONAHA.111.08721 3

[2] Fan, S. H., \& Say, Y. H. (2014). Leptin and leptin receptor gene polymorphisms and their association with plasma leptin levels and obesity in a multi-ethnic Malaysian suburban population. Journal of Physiological
Anthropology, 33(1), 1-10. https://doi.org/10.1186/18806805-33-15

[3] Crujeiras A. B., A. Díaz-Lagares, M. C. Carreira, M. Amil \& F. F. Casanueva (2013) Oxidative stress associated to dysfunctional adipose tissue: a potential link between obesity, type 2 diabetes mellitus and breast cancer, Free Radical Research, 47:4, 243-256, DOI: 10.3109/10715762.2013.772604

[4] Yu K, Yang J, Jiang Y, Song R, Lu Q. 2014. Vitamin D receptor BsmI polymorphism and colorectal cancer risk: an updated analysis. Asian Pacific Journal of Cancer Prevention 15(12):4801_4807 DOI 10.7314/APJCP.2014.15.12.4801Zhao L, Shen ZX, Luo HS, Shen L. Possible involvement of leptin and leptin receptor in developing gastric adenocarcinoma. World J Gastroenterol 2005; 11: 7666-7670.

[5] Robsahm TE, Aagnes B, Hjartåker A, Langseth H, Bray FI, Larsen IK. 2013. Body mass index, physical activity, and colorectal cancer by anatomical subsites. European Journal of Cancer Prevention 22(6):492_505 DOI 10.1097/CEJ.0b013e328360f434.

[6] Kim H. R. (2015). Obesity-Related Colorectal Cancer: The Role of Leptin. Annals of coloproctology, 31(6), 209-210. doi:10.3393/ac.2015.31.6.209

[7] Hamilton SR, Bosman FT, Boffetta P, et al. Carcinoma of the colon and rectum. In: WHO Classification of Tumours of the Digestive System. Bosman FT, Carneiro F, Hruban RH, Theise ND, eds. Lyon: IARC Press, 2010:134-46.

[8] Goodwin PJ, Stambolic V. 2015. Impact of the obesity epidemic on cancer. Annual Review of Medicine 66:281_296 DOI 10.1146/annurev-med-051613-012328.

[9] Kuryszko J, Sawuta P, Sapikowski G. 2016. Secretory function of adipose tissue. Polish Journal of Veterinary Sciences 19(2):441_446 DOI 10.1515/pjvs-2016-0056.

[10] Booth A, Magnuson A, Fouts J, Foster MT. 2016. Adipose tissue: an endocrine organ playing a role in metabolic regulation. Hormone Molecular Biology and Clinical Investigation 26(1):25_42 DOI 10.1515/hmbci2015-0073.

[11] Friedman JM, Mantzoros CS. 2015. 20 years of leptin: from the discovery of the leptin gene to leptin in our therapeutic armamentarium. Metabolism: Clinical and Experimental 64(1):1_4 DOI 10.1016/j.metabol.2014.10.023.

[12] Lipsey CC, Harbuzariu A, Daley-Brown D, GonzalezPerez RR. 2016. Oncogenic role of leptin and Notch interleukin-1 leptin crosstalk outcome in cancer. World Journal of Methodology 6(1):43_55 DOI 10.5662/wjm.v6.i1.43.

[13] Schwartz MW, Woods SC, Porte D, Seeley RJ, Baskin DG. 2000. Central nervous system control of food intake. Nature 404(6778):661671 DOI 10.1038/35007534.

[14] Ha S, Baver S, Huo L, Gata A, Hairston J, Huntoon N, Li W, Zhang T, Benecchi EJ, Ericsson M, Hentges ST, Bjørbæk C. 2013. Somato-dendritic localization and signaling by leptin receptors in hypothalamic POMC and AgRP neurons. PLOS ONE 8(10):e77622 DOI 10.1371/journal.pone.0077622.

[15] Allison MB, Myers MG. 2014. 20 years of leptin: connecting leptin signaling to biological function. Journal of Endocrinology 223(1):T25T35 DOI 10.1530/JOE-14-0404. 
[16] Hoggard N, Hunter L, Duncan JS, Williams LM, Trayhurn P, Mercer JG. 1997. Leptin and leptin receptor mRNA and protein expression in the murine fetus and placenta. Proceedings of the National Academy of Sciences of the United States of America 94(20):110738 DOI 10.1073/pnas.94.20.11073.

[17] Masuzaki H, Ogawa Y, Sagawa N, Hosoda K, Matsumoto T, Mise H, Nishimura H, Yoshimasa $\mathrm{Y}$, Tanaka I, Mori T, Nakao K. 1997. Nonadipose tissue production of leptin: leptin as a novel placenta-derived hormone in humans. Nature Medicine 3(9):10291033 DOI 10.1038/nm0997-1029.

[18] Smith-Kirwin SM, O'Connor DM, De Johnston J, Lancey ED, Hassink SG, Funanage VL. 1998. Leptin expression in human mammary epithelial cells and breast milk. Journal of Clinical Endocrinology and Metabolism 83(5):18101813 DOI 10.1210/jcem.83.5.4952.

[19] Hardwick, James C. H., Van Den Brink, Gijs R., Offerhaus, G. J., Van Deventer, Sander J. H., \& Peppelenbosch, Maikel P. (2001). Leptin is a growth factor for colonic epithelial cells. Gastroenterology, 121(1), 79-90.

[20] Bado A, Levasseur S, Attoub S, Kermorgant S, Laigneau JP, Bortoluzzi MN, Moizo L, Lehy T, Guerre-Millo M, Le Marchand-Brustel Y, Lewin MJ. 1998. The stomach is a source of leptin. Nature 394(6695):790793 DOI $10.1038 / 29547$.

[21] Sauter ER, Garofalo C, Hewett J et al. Leptin expression in breast nipple aspirate fluid (NAF) and serum is influenced by body mass index (BMI) but not by the presence of breast cancer. Horm Metab Res 2004; 36: 336-340.

[22] Neville MC, McFadden TB, Forsyth I. Hormonal regulation of mammary differentiation and milk secretion. J Mammary Gland Biol Neoplasia 2002; 7: 4966.

[23] Sulkowska M, Golaszewska J, Wincewicz A et al. Leptin - from regulation of fat metabolism to stimulation of breast cancer growth. Pathol Oncol Res 2006; 12: 6972.

[24] Garofalo C, Koda M, Cascio S et al. Increased expression of leptin and the leptin receptor as a marker of breast cancer progression: possible role of obesityrelated stimuli. Clin Cancer Res 2006; 12: 1447-1453.

[25] Garofalo C, Surmacz E. Leptin and cancer. J Cell Physiol 2006; 207: 12-22. 7

[26] Koda M, Sulkowska M, Wincewicz A et al. Expression of leptin, leptin receptor, and hypoxia-inducible factor 1a in human endometrial cancer. Ann N Y Acad Sci 2007; 1095: 90-8.

[27] Liu H, Wan D, Pan Z, Cao L, Wu X, Lu Z, Kang T. 2011. Expression and Biological Significance of Leptin, Leptin Receptor, VEGF, and CD34 in Colorectal Carcinoma. Cell Biochemistry and Biophysics 60(3):241244 DOI 10.1007/s12013-010-9145-5.

[28] Attoub S, Noe V, Pirola L et al. Leptin promotes invasiveness of kidney and colonic epithelial cells via phosphoinositide 3-kinase-, rho-, and rac-dependent signaling pathways. FASEB J 2000; 14: 2329-2338.

[29] Frankenberry KA, Somasundar P, McFadden DW, VonaDavis LC. Leptin induces cell migration and the expression of growth factors in human prostate cancer cells. Am J Surg 2004; 188: 560-565.
[30] Saxena NK, Sharma D, Ding X et al. Concomitant activation of the JAK/STAT, PI3K/AKT, and ERK signaling is involved in leptin-mediated promotion of invasion and migration of hepatocellular carcinoma cells. Cancer Res 2007; 67: 2497-2507.

[31] Khan, Unab I, Wang, Dan, Sowers, Maryfran R, Mancuso, Peter, Everson-Rose, Susan A, Scherer, Philipp E, \& Wildman, Rachel P. (2012). Race-ethnic differences in adipokine levels: the Study of Women's Health Across the Nation (SWAN). Metabolism, 61(9), 1261-1269.

[32] Azrad, Maria, Gower, Barbara A, Hunter, Gary R, \& Nagy, Tim R. (2013). Racial differences in adiponectin and leptin in healthy premenopausal women. Endocrine, 43(3), 586-592.

[33] Al-Shibli SM, Amjad NM, Al-Kubaisi MK, Harun N, Nafie EM, et al. (2018) Serum leptin might be causally correlated to Invasive Ductal Breast Carcinoma. J Clin Exp Oncol 7:1.

[34] Koda M, Sulkowska M, Kanczuga-Koda L, Cascio S, Colucci G, Russo A, Surmacz E, Sulkowski S. 2007a. Expression of the obesity hormone leptin and its receptor correlates with hypoxia-inducible factor-1 in human colorectal cancer. Annals of Oncology 18(SUPPL. 6):116119 DOI 10.1093/annonc/mdm238.

[35] Al-Maghrabi JA, Qureshi IA, Khabaz MN. 2018. Expression of leptin in colorectal adenocarcinoma showed significant different survival patterns associated with tumor size, lymphovascular invasion, distant metastasis, local recurrence, and relapse of disease in the western province of Saudi Arabia. Medicine 97(34):e12052 DOI 10.1097/MD.0000000000012052.

[36] WHO (2015). Obesity and overweight. Fact sheet $\mathrm{N}^{\circ} 311$. World Health Organization, Geneva; 2015.

[37] Abu Hassan, M. R., Ismail, I., Mohd Suan, M. A., Ahmad, F., Wan Khazim, W. K., Othman, Z., ... Nik Mustapha, N. R. (2016). Incidence and mortality rates of colorectal cancer in Malaysia. Epidemiology and health, 38, e2016007. doi:10.4178/epih.e2016007

[38] Hopkins, B. D., Goncalves, M. D., \& Cantley, L. C. (2016). Obesity and cancer mechanisms: Cancer metabolism. Journal of Clinical Oncology, 34(35), 42774283.

[39] Dong, Y., Zhou, J., Zhu, Y., Luo, L., He, T., Hu, H., Teng, Z. (2017). Abdominal obesity and colorectal cancer risk: systematic review and meta-analysis of prospective studies. Bioscience reports, 37(6), BSR20170945. doi:10.1042/BSR20170945

[40] Al-Shibli, S. M., Amjad, N. M., Al-Kubaisi, M. K., \& Mizan, S. (2017). Subcellular localization of leptin and leptin receptor in breast cancer detected in an electron microscopic study. Biochemical and biophysical research communications, 482(4), 1102-1106.

[41] Esper, Raymond M, Dame, Michael, McClintock, Shannon, Holt, Peter R, Dannenberg, Andrew J, Wicha, Max S, \& Brenner, Dean E. (2015). Leptin and Adiponectin Modulate the Self-renewal of Normal Human Breast Epithelial Stem Cells. Cancer Prevention Research, 8(12), 1174-1183.

[42] Chen, Chiachen, Yuan-Ching Chang, Chien-Liang Liu, Tsang-Pai Liu, King-Jen Chang, and Ing-Cherng Guo. 2007. "Leptin Induces Proliferation and Anti-Apoptosis in Human Hepatocarcinoma Cells by up-Regulating 
Cyclin D1 and down-Regulating Bax via a Janus Kinase 2-Linked Pathway." Endocrine-Related Cancer 14 (2):DOI:10.1677/ERC-06-0027.

[43] Steppan, C M, D T Crawford, K L Chidsey-Frink, H Ke, and A G Swick. 2000. "Leptin Is a Potent Stimulator of Bone Growth in Ob/ob Mice.” Regulatory Peptides 92 (1-3): 73-78. NCBI.nlm.nih.gov/pubmed/11024568.

[44] Somasundar, Ponnandai, McFadden, David W, Hileman, Stanley M, \& Vona-Davis, Linda. (2004). Leptin is a growth factor in cancer. Journal of Surgical Research, 116(2), 337-349.

[45] Gonzalez, Ruben R, Salandre Cherfils, Maria Escobar, Jin $\mathrm{H}$ Yoo, Cecilia Carino, Aaron K Styer, Brian $\mathrm{T}$ Sullivan, et al. 2006. "Leptin Signaling Promotes the Growth of Mammary Tumors and Increases the Expression of Vascular Endothelial Growth Factor (VEGF) and Its Receptor Type Two (VEGF-R2)." The Journal of Biological Chemistry 281 (36): 26320-28. DOI:10.1074/jbc.M601991200.

[46] Surmacz, Eva. 2013. "Leptin and Adiponectin: Emerging Therapeutic Targets in Breast Cancer." Journal of Mammary Gland Biology and Neoplasia 18 (3-4): DOI:10.1007/s10911-013-9302-8.

[47] Uddin, Shahab, Rong Bu, Maqbool Ahmed, Jehad Abubaker, Fouad Al-Dayel, Prashant Bavi, and Khawla S Al-Kuraya. 2009. "Overexpression of Leptin Receptor Predicts an Unfavorable Outcome in Middle Eastern Ovarian Cancer." Molecular Cancer 8:DOI:10.1186/1476-4598-8-74.

[48] Hoon Kim, Jung, Shin Young Lee, Soon Chul Myung, Young Sun Kim, Tae-Hyoung Kim, and Mi Kyung Kim. 2008. "Clinical Significance of the Leptin and Leptin Receptor Expressions in Prostate Tissues.” Asian Journal of Andrology DOI:10.1111/j.1745-7262.2008.00438.x.

[49] Howard, J M, P Beddy, D Ennis, M Keogan, G P Pidgeon, and J V Reynolds. 2010. "Associations between Leptin and Adiponectin Receptor Upregulation, Visceral
Obesity and Tumor Stage in Oesophageal and Junctional Adenocarcinoma." The British Journal of Surgery 97 DOI:10.1002/bjs.7072.

[50] Ishikawa, Makoto, Kitayama, Joji, \& Nagawa, Hirokazu. (2004). Enhanced expression of leptin and leptin receptor (OB-R) in human breast cancer. Clinical Cancer Research, 10(13), 4325-4331.

[51] Niu, Jingping, Jiang, Le, Guo, Weiheng, Shao, Liang, Liu, Yi, \& Wang, Liqin. (2013). The association between leptin level and breast cancer: a meta-analysis. PloS one, 8(6), e67349.

[52] Riondino S, Roselli M, Palmirotta R, et al (2014). Obesity and colorectal cancer: Role of adipokines in tumor initiation and progression. World J Gastroenterol, 20, 5177-90.

[53] Stattin P, Palmqvist R, Soderberg S, et al. (2015). Plasma leptin and colorectal cancer risk: a prospective study in Northern Sweden. Oncol Rep 2003;10:2015 - 21.

[54] Wang, D., Gao, L., Gong, K., Chai, Q., \& Wang, G. (2017). Increased serum leptin level in overweight patients with colon carcinoma: A cross-sectional and prospective study. Molecular and clinical oncology, 6(1), 75-78. doi:10.3892/mco.2016.1087

[55] Arpaci, F., Yilmaz, M. I., Ozet, A., Ayta, H., Ozturk, B., Komurcu, S., \& Ozata, M. (2002). Low Serum Leptin Level in Colon Cancer Patients without Significant Weight Loss. Tumori Journal, 88(2), 147-149. https://doi.org/10.1177/030089160208800213

[56] Sălăgeanu, A., Tucureanu, C., Lerescu, L., Caraş, I., Pitica, R., Gangurà, G., Neagu, S. (2010). Serum levels of adipokines resistin and leptin in patients with colon cancer. Journal of medicine and life, 3(4), 416-420.

[57] Jeong, W. K., Baek, S. K., Kim, M. K., Kwon, S. Y., \& Kim, H. S. (2015). Prognostic Significance of Tissue Leptin Expression in Colorectal Cancer Patients. Annals of coloproctology, 31(6), 222-227. doi:10.3393/ac.2015.31.6.222 